\title{
PERANCANGAN SISTEM PELAYANAN KELURAHAN DIGITAL TERPADU (SIPERDIT) BERBASIS PROGRESSIVE WEB APP (PWA)
}

\author{
Ahmad Faisol ${ }^{1}$, Sidik Noertjahjono ${ }^{2}$ \\ ${ }^{1,2)}$ Teknik Informatika S1 Fakultas Teknologi Industri - ITN Malang \\ mzfais@lecturer.itn.ac.id
}

\begin{abstract}
ABSTRAK
Pelayanan administrasi kependudukan yang berhubungan dengan proses surat - menyurat adalah salah satu layanan yang diberikan oleh pemerintahan di tingkat Desa atau Kelurahan. Pada kenyataannya, proses pengurusan surat - menyurat ini masih dilakukan dengan cara yang semi manual, dimana warga masih harus datang ke lokasi pelayanan yang terkadang sampai berkali - kali karena ketidaktahuan persyaratan yang harus dipenuhi, petugas yang tidak ada di tempat, atau karena alasan lain. Sejauh ini sudah ada yang mengembangkan aplikasi pelayanan semacam ini akan tetapi masih kurang efektif karena warga harus mengisi formulir data diri setiap mengajukan permohonan. Oleh karena itu, peneliti merancang sebuah sistem pelayanan yang dapat memudahkan warga untuk mengurus administrasi kependudukan. Metode yang digunakan pada perancangan sistem ini adalah Prototype Methodology, dimana akan dikembangkan prototip terlebih dahulu sebelum menjadi aplikasi yang benar - benar siap pakai. Arsitektur sistem mini terdiri dari 2 jenis modul, yaitu modul berbasis PWA (Progressive Web App) yang akan digunakan oleh warga dan petugas di tingkat RT/RW, dan aplikasi berbasis web yang akan digunakan oleh petugas di tingkat Desa atau Kelurahan. Hasil perancangan menunjukkan bahwa sistem lebih efektif dan efisien dalam memberikan pelayanan karena aplikasi ini dapat digunakan di segala macam perangkat telepon pintar (smartphone) baik berbasis Android maupun IOS. Warga tidak perlu lagi harus bolak - balik untuk mengurus permohonan surat karena pengajuan langsung dilakukan secara online dan tinggal menunggu validasi dari RT/RW dan setelah dicetak oleh petugas Desa atau Kelurahan, warga akan mendapatkan notifikasi untuk mengambil surat yang sudah disahkan oleh Kepala Desa atau Lurah.
\end{abstract}

Keyword : sistem pelayanan kelurahan, administrasi kependudukan, progressive web app.

\section{PENDAHULUAN}

Sistem administrasi kependudukan digital tidak hanya berkisar pada administrasi Kartu Tanda Penduduk secara elektronik (e-KTP) saja, melainkan dapat berupa administrasi surat menyurat bagi seluruh warga yang berkepentingan dengan organisasi kepemerintahan pada tingkat yang paling rendah hingga tingkat - tingkat di atasnya. Pada prosesnya, setiap warga yang membutuhkan pelayanan administrasi di tingkat RT/RW maupun kelurahan, harus mengajukan permohonan dengan mendatangi lokasi pelayanan mulai dari rumah Ketua RT, Ketua RW, hingga kantor Kelurahan / Desa. Permasalahan muncul ketika petugas yang dituju sedang tidak di tempat, atau persyaratan administrasi yang belum diketahui yang menyebabkan warga harus bolak - balik ke tempat pelayanan.

Salah satu perkembangan di bidang teknologi informasi saat ini, yaitu teknologi web progresif atau lebih dikenal dengan Progressive Web App (PWA). PWA adalah sebuah website yang dibangun menggunakan teknologi web modern, namun dapat berlaku seperti sebuah Mobile App (Santoso, 2019). Dengan memanfaatkan teknologi PWA, aplikasi berbasis web dapat dikembangkan hanya dengan menggunakan teknologi HTML, CSS, dan Javascript, serta dapat dijalankan layaknya aplikasi native pada perangkat dengan sistem operasi Android dan IOS.

Pada penelitian ini, penulis melakukan analisis dan perancangan sistem pelayanan dengan menyesuaikan kebutuhan di tingkat kelurahan menggunakan teknologi PWA.

\section{TINJAUAN PUSTAKA}

2.1. Administrasi Kependudukan

Adminsitrasi kependudukan yang dimaksud disini adalah prosedur dan proses surat menyurat sehari-hari dalam lingkup organisasi pemerintahan pada tingkat kelurahan hingga jenjang Rukun Tetangga (RT) di wilayahnya.

Surat menyurat yang dimaksud disini adalah proses pengajuan dari warga untuk mendapatkan Surat Pengantar dan pengesahan dari pejabat tertinggi di wilayah dimana warga tersebut berdomisili, misalnya sesorang akan melaksanakan pernikahan, yang bersangkutan harus mendapatkan Surat Keterangan Penduduk dan disahkan oleh pejabat yang berwenang, dalam hal ini adalah Lurah atau Kepala desa diwilayahnya.

Untuk maksud pengurusan administrasi surat menyurat ini, warga terkait harus melaksanakan pengurusan dan proses surat menyurat dari tingkat RT hingga jenjang di tingkat Kelurahan. Dalam proses konvensional, yang bersangkutan akan membutuhkan waktu dan tenaga yang banyak, namun dengan sistem administrasi kependudukan digital terpadu ini, setiap warga yang melakukan proses surat menyurat dapat menghemat tenaga dan waktunya, terutama yang memang setiap harinya mempunyai tugas pokok pekerjaan yang tidak dapat ditinggalkan se-waktu-waktu.

\subsection{Surat}

Surat merupakan suatu alat komunikasi tertulis dari satu pihak yang ditujukan kepada pihak lain 
untuk menyampaikan warta (Barthos, 2003). Sedangkan menurut Gie (2000), surat adalah setiap bentuk catatan tertulis atau bergambar yang memuat keterangan mengenai sesuatu hal atau peristiwa yang dibuat orang untuk membantu ingatannya.

Akan tetapi dibandingkan alat komunikasi yang lain surat memiliki kelebihan tersendiri, hal ini dikarenakan surat merupakan sarana yang dapat merekam informasi jauh lebih panjang, lebih rinci namun tetap praktis dan ekonomis. Dalam hal ini surat bersifat praktis yang artinya dapat menyimpan rahasia, efektif artinya sesuai dengan keadaan yang sebenarnya dan ekonomis artinya biaya pembuatan, peralatan dan pengirimannya murah. Dari beberapa penjelasan diatas maka dapat ditarik kesimpulan bahwa surat adalah alat komunikasi yang berisi informasi baik tertulis maupun bergambar yang hendak disampaikan kepada pihak lain yang bersangkutan dan memiliki kelebihan tersendiri dalam hal kerahasiaan, keefektifan dan ekonomis. Jadi dari beberapa pengertian di atas dapat disimpulkan bahwa surat adalah alat komunikasi yang secara tertulis untuk menyampaikan informasi.

\subsubsection{Surat Masuk}

Surat masuk adalah surat yang diterima dari perusahaan atau instansi lain kepada pihak yang bersangkutan. Surat masuk merupakan saran komunikasi tertulis yang diterima dari instansi atau perorangan. Dapat pula diartikan, surat masuk adalah semua jenis surat yang diterima dari instansi lain maupun perorangan, baik yang diterima melalui pos maupun yang diterima dari kurir dengan mempergunakan buku pengiriman (Wursanto, 1991).

Pengendalian dan pengurusan surat masuk dalam instansi dapat digolongkan menurut penggolongan jenis surat yaitu (Wursanto, 1991):

1. Surat penting Semua surat yang mengemukakan semua masalah-masalah pokok yang memepengaruhi langsung ataupun tidak langsung, berhasil tidaknya pencapaian tujuan organisasi.

2. Surat rutin atau biasa Surat yang tidak tergolong penting, dimana surat-surat tersebut langsung di tindak lanjuti, relatif singkat dan tidak disimpan terlalu lama.

3. Surat rahasia Surat yang harus disampaikan sesegera mingkin kepada pimpinan (orang yang bersangkutan) yang masih dalam keadaan tertutup, sehingga surat tersebut tidak boleh dibuka oleh penerima surat.

4. Surat pribadi Surat yang disimpulkannya tercantum nama pribadi orang yang bersangkutan, walaupun disertai jabatan formalnya.

\subsubsection{Surat Keluar}

Surat keluar yaitu surat yang dikirim dari pihak baik instansi, organisasi atau perusahaan yang berisi tentang suatu informasi atau data baik itu perintah, pemberitahuan maupun informasi lainnya. Surat keluar adalah surat yang sudah lengkap (bertanggal, bernomor, berstempel dan telah ditandatangani oleh pejabat yang berwenang yang dibuat oleh suatu instansi atau lembaga lain) (Wursanto, 1991).

\subsection{Progressive Web App (PWA)}

Pada dasarnya, Progressive Web App (PWA) adalah sebuah website yang dibangun menggunakan teknologi web modern, namun dapat berlaku seperti sebuah Mobile App (Santoso, 2019). Pada tahun 2015, Google Engineer Alex Russel dan Frances Berriman memberikan istilah PWA pada konsep web apps yang dapat memberikan pengalaman pengguna dalam keandalan (reliability), kecepatan (speed), dan keterlibatan pengguna (user engagement).

Google berusaha memastikan bahwa aplikasi web progresif ini dapat memberikan pengalaman ke pengguna seperti aplikasi native. PWA memiliki beberapa kelebihan, yaitu memiliki respon seperti mobile app, responsive layout, tersedia di mode offline, memiliki ikon yang dapat ditambahkan ke layar home screen perangkat, dapat mengirim dan menerima notifikasi. Akan tetapi teknologi PWA juga memiliki beberapa kelemahan, seperti notifikasi yang hanya bisa dijalanan pada protokol jaringan HTTPS, berjalan dengan baik hanya pada perambah (browser) modern dan untuk saaat ini belum semua browser mendukung teknologi PWA secara penuh.

\section{METODOLOGI PENELITIAN}

Metode penelitian yang digunakan untuk merancang sistem pelayanan kelurahan ini adalah Prototype Methodology (Shelly \& Rosenblatt, 2012) seperti yang ditunjukkan pada Gambar 1. Metode ini lebih fokus kepada pengembangan prototip dari setiap solusi yang ditawarkan dan membuat modifikasi yang dibutuhkan sebelum dikembangkan pada aplikasi yang sesungguhnya.

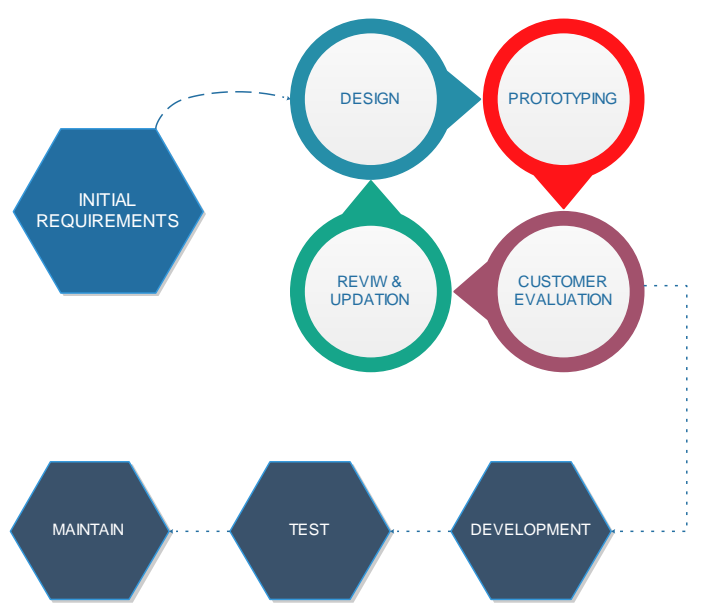

Gambar 1. Alur Metode Prototip

Tahap pertama yang dilakukan adalah melakukan analisis kebutuhan sistem, yaitu 
kebutuhan fungsional dan non fungsional. Setelah kedua kebutuhan tersebut divalidasi, maka proses pengembangan masuk ke tahap desain. Pada tahap ini, peneliti menterjemahkan hasil analisis menjadi sebuah desain prototip maupun desain aplikasi, seperti Flowchart alur sistem, Use Case Diagram, desain basis data, dan desain antar muka. Tahap berikutnya adalaha mengimplementasikan hasil desain menjadi sebuah aplikasi berbasis web dan PWA. Perangkat lunak yang digunakan untuk implementasi antara lain Codeigniter Framework, DBMS MySQL, JQuery, CSS, dan Visual Studio Code sebagai editor. Sedangkan untuk kebutuhan pengiriman notifikasi, menggunakan OneSignal dan Firebase Cloud Messaging.

Setelah prototip selesai dikembangkan, baru kemudian didemonstrasikan kepada klien untuk mengetahui kekurangan atau fungsi - fungsi yang dibutuhkan oleh klien. Setelah dilakukan penilaian oleh klien, proses akan berlanjut kepada tahap perbaikan - perbaikan (jika ada) berdasarkan hasil penilaian klien. Jika prototip sudah benar - benar sesuai kebutuhan pengguna, maka aplikasi dikembangkan lagi dengan menambah beberapa fitur tambahan agar siap digunakan oleh pengguna.

\section{HASIL DAN PEMBAHASAN}

\subsection{Arsitektur Sistem}

Kebutuhan perancangan sistem pelayanan terpadu di kelurahan ini dimulai dengan menggambarkan arsitektur dan alur kerja dari sistem yang akan dikembangkan.

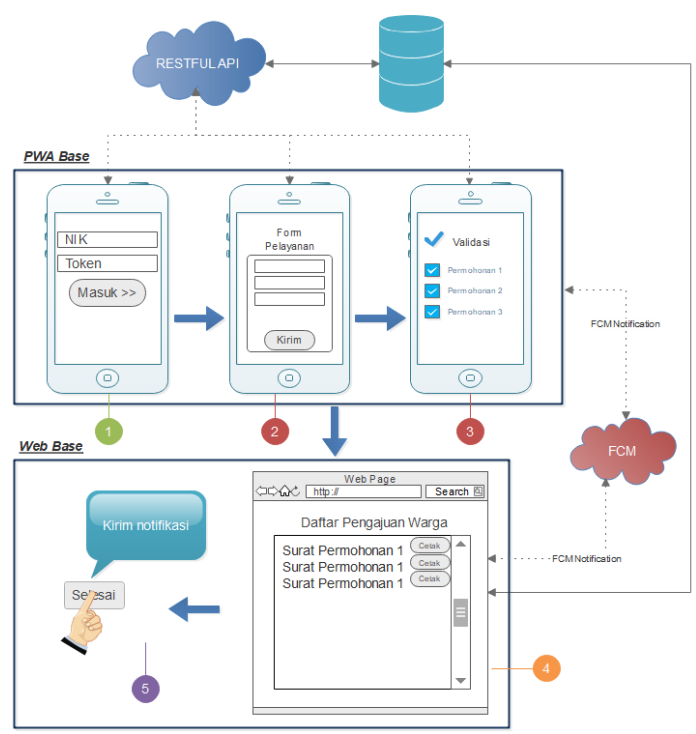

Gambar 2. Arsitektur dan Alur Sistem

Gambar 2 menjelaskan tentang arsitektur dan alur dari sistem yang akan dikembangkan. Terdapat 5 bagian penting yang terdiri dari Database Server,
Web Front-end, RESTful API, Firebase Content Messaging (FCM), dan PWA.

Web Front-end berfungsi sebagai antarmuka yang akan diakses oleh pegawai kelurahan untuk melakukan pendataan dan mencetak pengajuan surat dari warga. Sedangkan $P W A$ berfungsi sebagai antarmuka yang akan diakses oleh warga dan petugas RT/RW melalui perangkat bergerak (Smartphone) dan memiliki fungsi utama sebagai aplikasi untuk mengirim pengajuan pelayanan ke Kelurahan, seperti surat keterangan tidak mampu, surat keterangan domisili, surat kelahiran, dan lain lain serta proses validasi oleh petugas RT/RW.

RESTful API berfungsi sebagai penyedia layanan bagi $P W A$ untuk mengirim atau meminta data. Sedangkan FCM berfungsi untuk mengirim notifikasi dari aplikasi ke perangkat pengguna, baik dari PWA ke Web Front-end maupun sebaliknya.

Berdasarkan Gambar 4, dapat dilihat bahwa alur dari sistem dimulai dari warga yang mengakses aplikasi PWA dari perangkat mereka untuk mengajukan permohonan surat kepada Kelurahan. $P W A$ akan meminta dan mengirim data ke Database Server melalui layanan RESTful API. Permohonan layanan kelurahan dapat diakses jika warga sudah melakukan otentikasi pada aplikasi, dimana data yang digunakan untuk otentikasi adalah NIK dan Token, yang dapat diminta ke petugas kelurahan. Jika otentikasi berhasil, warga dapat mengakses layanan dan mengisi formulir pengajuan surat yang dibutuhkan, dan apabila berhasil aplikasi $P W A$ akan mengirimkan notifikasi melalui $F C M$ kepada perangkat petugas di tingkat RT.

Petugas RT harus melakukan validasi terhadap permohonan yang dikirimkan oleh warga, jika validasi berhasil maka petugas di tingkat RW juga akan menerima notifikasi dan harus melakukan validasi agar bisa dicetak oleh petugas di tingkat Desa atau Kelurahan.

Setelah melalui tahap validasi oleh RT/RW, notifikasi akan diterima oleh petugas di kantor Desa / Kelurahan, kemudian surat permohonan dari warga dapat diunduh melalui aplikasi Web Front-end dan dicetak agar kemudian bisa ditanda tangani oleh Petugas berwenang (Kepala Kelurahan atau Kepala Desa). Setelah proses tersebut selesai, petugas harus mengirimkan notifikasi kepada warga yang mengajukan permohonan untuk memberitahukan bahwa surat permohonan sudah selesai dan dapat diambil di Kantor Kelurahan atau Kantor Desa.

\subsection{Use Case Diagram}

Desain Use Case Diagram memberikan gambaran tentang layanan atau fitur yang ada pada sistem serta siapa saja pengguna yang berhak mengakses fitur tersebut. Desain fitur dan layanan tersebut dapat dilihat pada Gambar 5. 


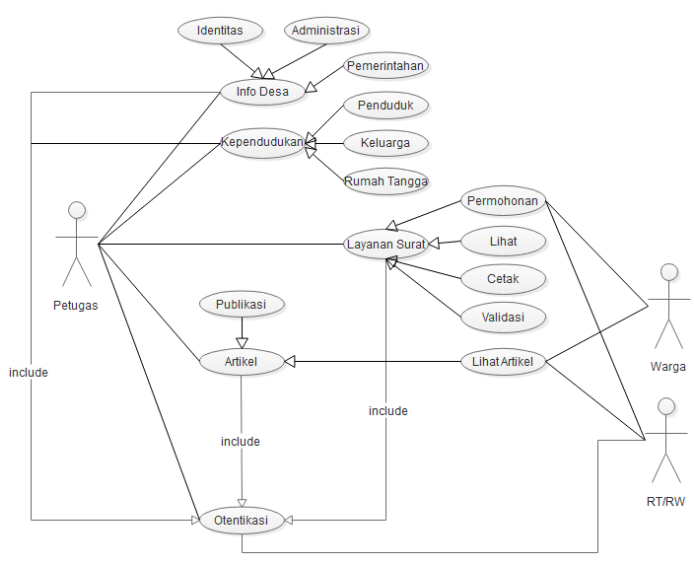

Gambar 3. Desain Use Case Diagram

Berdasarkan Gambar 3, dapat dijelaskan bahwa terdapat 3 jenis pengguna pada sistem ini, yaitu Petugas (Pegawai Desa / Kelurahan), Petugas di tingkat RT/RW, dan Warga. Petugas di tingkat Desa / Kelurahan berhak mengelola sistem dengan memiliki akses terhadap beberapa Use Case, antara lain Info Desa, Kependudukan, Layanan Surat, dan Kelola Artikel.

Layanan Info Desa terdiri dari kelola Identitas Desa, Wilayah Administratif, dan Pemerintahan Desa. Layanan Kependudukan terdiri dari kelola data Penduduk, Keluarga, dan Rumah Tangga. Layanan Surat merupakan layanan utama pada sistem ini. Pada layanan ini, petugas memiliki akses untuk membuatkan surat permohonan bagi warga yang masih dating langsung ke kantor desa atau kelurahan, melihat daftar surat permohonan, dan mencetak surat permohonan yang dikirim oleh warga secara online maupun yang datang langsung ke kantor desa atau kelurahan. Jadi, kelebihan dari sistem ini adalah petugas bisa mencetak langsung setiap surat permohonan yang dikirim oleh warga melalui aplikasi SIPERDIT secara online. Layanan yang terakhir adalah kelola Artikel yang berisi berita atau pengumuman tentang Desa / Kelurahan.

Sedangkan warga memiliki akses terhadap 2 layanan utama, yaitu akses berita terbaru dan mengirim surat permohonan. Pada layanan Permohonan ini, warga sebelumnya harus melakukan otentikasi dengan menggunakan Nomor Induk Kependudukan (NIK) dan kode token yang dapat diperoleh melalui petugas. Jika otentikasi warga benar, maka warga dapat memilih layanan surat yang dibutuhkan dan mengirim surat permohonan. Setelah permohonan dikirim, petugas akan mendapatkan notifikasi untuk segera mencetak surat tersebut. Setelah ditandatangani oleh pejabat berwenang dan dinyatakan status permohonan telah selesai, warga dapat mendatangi kantor desa atau kelurahan untuk mengambil surat yang telah diajukan.

Petugas di tingkat RT/RW memiliki hak akses yang hampir sama seperti warga, perbedaannya adalah pengguna ini memiliki hak akses untuk melakukan validasi setiap permohonan yang dikirim oleh warga. Sehingga, setiap permohonan yang masuk, harus divalidasi terlebih dahulu oleh RT yang dilanjutkan proses validasi oleh RW, baru kemudian permohonan tersebut dapat dicetak oleh petugas Desa / Kelurahan.

\section{KESIMPULAN DAN SARAN}

\subsection{Kesimpulan}

1. Arsitektur Sistem Pelayanan Kelurahan Digital Terpadu menunjukkan bahwa pelayanan surat bagi warga desa atau kelurahan dapat dilakukan secara lebih efektif dan efisien.

2. Dengan menerapkan sistem berbasis PWA, warga tidak perlu kesulitan untuk melakukan instalasi aplikasi, cukup dengan mengunjungi situs layanan desa dan akan mendapatkan pemberitahuan untuk menambahkan aplikasi di perangkat.

3. Dengan menerapkan Firebase Cloud Messaging (FCM) untuk mengirim notifikasi secara realtime, pelayanan surat permohonan bagi warga dapat segera diketahui dan ditindak lanjuti.

\subsection{Saran}

1. Diharapkan bagi pengembang aplikasi berbasis PWA agar menggunakan protokol HTTPS agar sistem berjalan lebih maksimal.

2. Sistem Pelayanan ini dapat dikembangkan dengan mengadopsi seluruh fitur pada PWA, seperti dapat menyimpan data secara offline.

\section{DAFTAR PUSTAKA}

[1]. Barthos, Basir. 2003. Manajemen Kearsipan. Jakarta: Bumi Aksara

[2]. Gie, The Liang. 2000. Administrasi Perkantoran. Yokyakarta: Modern Liberty

[3]. Masykur, Fauzan. 2015. Sistem Administrasi Pengelolaan Arsip Surat Masuk Dan Surat Keluar Berbasis Web. Universitas Muhammadiyah Ponorogo, Ponorogo

[4]. Santoso, Hendra. 2019. Membangun Aplikasi Mobile dengan PWA (Progressive Web App). Yogyakarta: CV. Lokomedia.

[5]. Shelly, G., \& Rosenblatt, H. (2012). System Analysis and Design. Ninth Edition. Course Technology. Cengage Learning.

[6]. Wursanto. 1991. Kearsipan 1. Yogyakarta: Kanisius Yogyakarta. 